\title{
Negotiating Ambivalent Gender Spaces for Collective and Individual Empowerment: Sikh Women's Life Writing in the Diaspora
}

\author{
Jaspal Kaur Singh $(\mathbb{1}$ \\ Department of English, Northern Michigan University, Marquette, MI 49855-5301, USA; jsingh@nmu.edu \\ Received: 18 May 2019; Accepted: 17 October 2019; Published: 28 October 2019 \\ check for \\ updates
}

\begin{abstract}
In order to examine gender and identity within Sikh literature and culture and to understand the construction of gender and the practice of Sikhi within the contemporary Sikh diaspora in the US, I analyze a selection from creative non-fiction pieces, variously termed essays, personal narrative, or life writing, in Meeta Kaur's edited collection, Her Name is Kaur: Sikh American Women Write About Love, Courage, and Faith. Gender, understood as a social construct (Butler, among others), is almost always inconsistent and is related to religion, which, too, is a construct and is also almost always inconsistent in many ways. Therefore, my reading critically engages with the following questions regarding life writing through a postcolonial feminist and intersectional lens: What are lived religions and how are the practices, narratives, activities and performances of 'being' Sikh imagined differently in the diaspora as represent in my chosen essays? What are some of the tenets of Sikhism, viewed predominantly as patriarchal within dominant cultural spaces, and how do women resist or appropriate some of them to reconstruct their own ideas of being a Sikh? In Kaur's collection of essays, there are elements of traditional autobiography, such as the construction of the individual self, along with the formation of communal identity, in the postcolonial life writing. I will critique four narrative in Kaur's anthology as testimonies to bear witness and to uncover Sikh women's hybrid cultural and religious practices as reimagined and practiced by the female Sikh writers.
\end{abstract}

Keywords: gender, religion and sexuality; Sikh literature and gender representations; Sikh diaspora and gender; lived religions and Sikhism; postcolonial life narratives and gender; trauma, testimonies and bearing witness

\section{Gender and Religion: A Theoretical Framework}

Gender, understood as a social construct (by Butler, among others), is almost always inconsistent and is related to religion, which, as a construct, is also almost always inconsistent in many ways. According to Ursula King,

Gender issues relating to religion are ubiquitous, but religion and gender are not simply two analogues which exist side by side and can be related to each other at the same level. They do not exist independently from each other, for patterns of gender are deeply embedded throughout all religion. (emphasis added; King 2005, p. 3)

Indeed, as King further explains, "This very embeddedness means that gender is initially difficult to separate out from other aspects of religion until one consciously makes a 'gender-centric turn'" (original emphasis 3). The Sikh religion, also a construct and presented as singular in dominant cultural spaces, is actually fluid and constantly shifting and changing through lived experiences of Sikh religious practitioners of all genders. The universal Spirit—Akal Purakh-is considered formless and timeless and one can be in communion with it simply through meditation and naam japna-the recitation of 
the name, as most Sikhs do. Guru Nanak (1469-1539), the founder of Sikhism, was a mystic, who, as a wandering ascetic, sang praises of one truth, describing it as Ek Onkar, Sat Nam, Karta Purakh, Nirbhau, Nirvair, Akal Purakh, and Ajuni Sahibang (there is one God whose name is Truth, is the doer, is fearless, formless, without enmity, manifested in the material world, and is neither created nor destroyed; author's translation). Women within the Sikh faith, I argue, practice the right to have an individual relationship with Akal Purakh and consider themselves true Sikhs even when estranged from their families or isolated from the Sikh community. While there is a considerable corpus of Sikh literature regarding Sikhism and some work on Sikh gendered identity, I will not be delving on the whole body of work, as it is beyond the scope of this article. Instead, in order to examine gender and identity within Sikh religious practices and culture for this article, I will analyze a small collection of creative non-fiction pieces, variously termed essays, personal narrative, or life writing, in Meeta Kaur's edited collection of personal essays, Her Name is Kaur: Sikh American Women Write About Love, Courage, and Faith - through an intersectional and postcolonial feminist framework. To understand the writers' negotiation for empowering identities within their families and their ideas of being Sikh as understood by them within the Sikh community in the diaspora, my critique will also include my own life narratives because, and as I have argued in my 2006 article Contrary Narrative Spaces and the Sikh Women, a gendered understanding of dominant narratives "necessitates a shift in the scholar's attention from the public to the private" by including "everyday accounts" from the private spaces of the home (Didur 2006, p. 7).

In the collection of essays, diaspora Sikh women showcase multigenerational and cross-cultural perspectives in terms of what it means to be a Sikh woman in transnational, often conflicted, social spaces. As Meeta Kaur, the editor of the collection, writes:

Sikh American women do the lion's share of organizing and executing the business of the Sikh community, and they straddle multiple lives and worlds-cross-cultural, intergenerational, occupational, and domestic - yet their experiences of faith, family, and community are virtually invisible in the North American milieu and have yet to be understood, documented, or shared. (Kaur 2014, p. 1)

Meeta Kaur's book attempts to fill the gap in Sikh gender literature by highlighting women writers who "celebrate their identities, [share their] stories, and [show their] capacity to love as Sikh American women" (Kaur 2014, p. 1). As diasporic Sikh women in the US, their stories are "woven," as N.G.K. Singh notes in the "Foreword," with "Sikh ideals, values, spaces and identity" (Singh 2014, p. 6), adding:

[They] share the greeting Sat Sri Akal and the ubiquitous Waheguru; they share the morning routine of the Japji and the evening Rahiras; they share the ceremonies of Anand Karaj (wedding) and Antim Ardas (at cremation); they share the feeling of exultation in the Babaji's room (enshrines Sikh sacred scripture); and the mesmerizing beauty of the Harmandar Sahib; they share the heartbreak of the 1984 violence back in India and the tragic 2012 shooting at the Gurudwara Sahib in Milwaukee. (Singh 2014, p. 6)

Sharing their stories bring the women together as a community, a "sangat" of Sikh men and women, according to Singh; for the purposes of this paper, I explore how the writers practice their Sikhi in the predominantly heteropatriarchal spaces of both their homes and the nation for individual and collective empowerment as they form their own ideas of Sikhi and "sangat."

N.G.K. Singh asserts that in the collection, Her Name is Kaur, the writers, mostly cisgendered women, assert their agency, for "Kaur" is an expression of radical change in the patrilineal structure (Singh 2014, p. 7). It is understood in Sikhism and Sikh culture that male Sikhs were given the name Singh, Lion, by Guru Gobind Singh, the last guru of the Sikhs during the Khalsa initiation rite of 1699 . In recent publications, however, it has been revealed that the name "Kaur" was bestowed upon Sikh women during the various reform movements when India was under British colonial rule. According to Nikky Singh, however, the name "Kaur" is traced to Guru Gobind Singh ("Preface", Her Name is 
Kaur). Doris Jakobsh contests this claim. In her book Relocating Gender in Sikh History, Jakobsh argues it was during the Singh Sabha Reform Movement of the late nineteenth and early twentieth centuries in India that the name Kaur was given to Sikh women (Jakobsh 2003, p. 218). Before this event, many Sikh women were either called Kumari or Devi (my maternal grandmother, a Sikh, who was born in Amritsar at the turn of the twentieth century, was named Maya Dai or Devi, but after she was married to an amritdhari Sikh man, she was renamed Bishan Kaur). Noting the difficulty of analyzing the "normative naming practices of the Sikh females" due, as Jakobsh notes, "to the scant sources available with regard to the appellation Kaur," she argues that "certitude can only be replaced by speculation-at best until the beginning of the twentieth century, Kaur as a feminine epithet can only be understood as indicative of a diffuse cultural identity but having not religious signification" (original emphasis; Jakobsh 2003, p. 223). Khushwant Singh, in his discussion of the names "Singh" and "Kaur" given to males and female Sikh by Guru Gobind Singh writes, "In making all Sikhs Singhs (and Kaurs) [Gobind Singh] made them into one casteless fraternity" (The Sikhs (Singh 2001)); as can be surmised from the above quote and the use of parenthesis, Kaurs are almost always parenthetical in the discussion of Sikh identity in Indian and Sikh literature and, it appears, as seen from Jakobsh's Relocating Gender in Sikh History (2003), in Sikh history.

Meeta Kaur defines the writers as "Sikh women, daughters of the Sikh Gurus" (Kaur 2014, p. 2), and having struggled to find empowering Sikh female voices, she decided to ask, "Sikh American women living in the United States" to tell their "truest stories of love" (Kaur 2014, p. 2). The fact that most of the essays (except for one queer narrative, which I shall discuss in some detail below) about finding empowerment and about "revisioning, renewal and rebirth" are about heteropatriarchal alliances—or love-with heteropatriarchal and turbaned amritdhari Sikh males is telling.

How can I, as a reading subject, a critic, a Sikh woman, interpret the testimonial life writing essays in ways that I can attempt to bear witness to their journey and struggles to find empowering spaces within a religion that promises gender equality but which is performed in dominant religious spaces as predominantly heteropatriarchal and masculinist? Can I provide "faithful witnessing" as a "decolonial" (Lugones 2003, p. 5) and anti-sexist practice? As Lugones argues, bearing witness challenges dominant narratives to locate multiple perspectives, particularly from those that are deemed invisible or placed in the margins. Faithful witnessing will uncover moments of collusion or resistance, violence or love with patriarchal ideology which are otherwise not clearly visible; they are located within the liminal spaces of the text and have to be uncovered through a postcolonial feminist and intersectional lens. I attempt to provide "faithful witnessing" to some of Kaur's collection of essays below to uncover resistant practices, but also to show female Sikhs' maneuvering within patriarchal spaces for a return to and reconciliation with the estranged traditional Sikh community.

My reading asks the following questions: What are "lived religions" and what are the everyday practices, narratives, activities, and performances of 'being' Sikh, particularly as they relate to women (cis and queer) practitioners, as represented by the writers? What are some of the everyday practices of Sikhism, viewed predominantly as patriarchal, and how the writers resist them to reconstruct their own ideas of being Sikh? Have religious boundaries shifted for Sikhs in the contemporary era, and if so, what are some of the innovations in Sikhi, the practice of Sikhism, particularly in terms of gender construction and representation for these writers?

In Kaur's collection of essays, there are elements of traditional autobiography in Sikh women's postcolonial life writing. For example, Gillian Whitlock, in Postcolonial Life Narratives: Testimonial Transactions, writes:

Traditional assumptions about autobiographical authorship and authority prioritize authenticity, autonomy, self-realization, and transcendence-western enlightenment values that, as Linda Andersen observes, associate autobiography with essentialist or romantic notions of selfhood and the 'sovereign subject' of autobiography as it was traditionally understood. (Whitlock 2015, p. 3) 
While there are elements of traditional autobiographical selfhood— - western enlightenment values" —in Kaur's collection of essays, what I am interested in are components of postcolonial and decolonizing life writing. Whitlock, quoting Sidonie Smith and Julia Watson, notes, "For postcolonial theory, the more expansive category 'life writing' is critical in de/colonizing literary cultures. The traditional sovereign subject of autobiography and the less exalted collective subject of life writing are entangled in western modernity" (Whitlock 2015, p. 3). Whitlock calls these hybrid entities "proximate subject of autobiography" (ibid., p. 3). We have to read narratives, such as the collection in Kaur's anthology, as testimonies "entangled in western modernity" by culturally hybrid writers. Whitlock, quoting Robert Young, notes that in testimonies the writers are intimately connected to the reader:

[Young] is right to suggest there is something dynamic and interactive about testimonial discourse, which is generically rhetorical and dialogic: an appeal to the addressee, a text in search of a witness, a desire to invoke witnessing public. We speak of bearing witness to indicate the weight of responsibility and affect that follows the transfer. Testimony enables accounts of social injustice and oppression, of violence and suffering. (original emphasis; Whitlock 2015, p. 8)

Subaltern subjects (which I consider Sikh women to be, myself included) are, according to Whitlock, "not voiceless and nor are they victims, however, their visibility, legibility, and audibility are tactical, contingent and constrained" (ibid., p. 8). As Meeta Kaur notes, Sikh women voices are lacking in the dominant narrative spaces, as male writers are provided a more privileged space in Sikh literature. Whitlock adds, "Testimonies can create a piercing and transformative 'bearing' witness that triggers advocacy, responsibility, accountability, which move the reader and produce collective 'witnessing publics" (ibid., p. 9). In my critical reading of essays from Kaur's collection, I attempt to bear witness to Sikh women's life writing in order to create a circuit of communication (Kopf 2009) through reading the gaps and ellipses in their writing. According to Martina Kopf,

Writing and reading are two poles, and all listening, witnessing, experiencing and remembering constantly move between one and the other. Good writers are maybe above all good listeners. That is to say, their skill consists to a large extent in the ability to be simultaneously sensitive to themselves, to the narratives of their time and to what these narratives evoke in themselves and in others. Furthermore, they are-or should be-able to hear what the narratives and the people of their time and their social surroundings conceal ... The same holds true to a certain degree for the reader. Reading-like writing-is a cultural practice that can be exerted with more or less quality. Literature as trauma witness does not only demand attentive writing but attentive reading as well. Active listening and a reading aware of the structure of trauma and of the effects of violence form part of the narrative transmission and transformation of traumatic memory. (emphasis added; Kopf 2009, p. 53)

Sikh women writing about religion, love and gender identity as US women of color within the patriarchal Sikh community asked to be read attentively, particularly for those of us who perform the act of witnessing to uncover alternative meanings for the writers and excavate ideas that might be "concealed" in the margin of the narratives within patriarchal communities.

First, let's examine gender broadly, as it is understood in gender and sexuality studies. Gender is constructed, circulated, and performed within patriarchal societies through social customs. As Susan Shaw and Janet Lee remind us,

It is important not to reduce ... 'performativity' associated with gender to a voluntary act or understand it as something over which we have perfect control. In this sense it is not merely a theatrical performance. Rather performativity is constrained by social norms. What this means is that gender is not only what we 'do'; it is a process by which we 'are' or 'become.' (Shaw and Lee 2015, p. 117) 
To understand how gender is shaped within society and how individuals express their gender, we need to examine, as Shaw and Lee posit, "gender assignment, identity and expression" (ibid., p. 119); the first is "usually assigned at birth and determined by our physical body type to be male or female;" the second "concerns how one feels internally about one's own gender ... and may or may not match one's assigned gender at birth;" the last—gender expression—is "how we perform or express gender to those around us" (ibid., p. 119). In this way, as Shaw and Lee remind us, "Gender is a pervasive theme in our world, shaping social life and informing attitudes, behavior, and individual's sense of self ... It is ... one of the foundational ways societies are organized (Shaw and Lee 2015, p. 119). Most cisgender women within the Sikh tradition perform their gender and their Sikhi in specific and socially prescribed ways, as they see Sikh religion as egalitarian (Parveen Kaur and Asif Jawaid Mongal, among others), although individual Sikh women-cis or queer-engage with traditions in their own, often resistant, ways since "Sikhness" or Sikh identity is often narrowly defined in Sikh tradition through the male body (as can be seen from various writers such as Doris Jakobsh's Relocating Gender in Sikh History and Sharapal Ruprai's Seva 2014).

Sikhs believe in a formless God who can be realized through daily prayers and meditation, as discussed above. Sikhs are supposed to believe in gender equality; for example, throughout my youth, I heard women, too, can be priests and perform the path and can preside over anand karaj; to be sure, I attempted to find textual proof, but I only found examples of them in articles, such as Role of Women in Sikhism on websites such as "WaheguruNet" or other religious sites. Yet, when we read or discuss about Sikh identity, we are predominantly relating the issue with the amritdhari (initiated into the Khalsa order) Sikh male, as I discuss below. Ruprai, for example, struggles between her identities as a Sikh and as a woman. She writes as a Sikh woman growing up in a Sikh Canadian household, "I feel a tug of resistance, that is, 'being Sikh' on one side and 'being a woman' on the other ... The interconnection between the two is lived within my own body and both shapes and is shaped by my personal environment" (Ruprai 2014, p. 33). Her writings in Seva, her poetry collection, highlights her resistance to patriarchal authorities within the gurudwara community attempting to ghettoize her within the kitchen spaces by rebelliously continuing to serve in the langar hall (Ruprai 2014, p. 35). ${ }^{1}$

For the Sikhs, trying to define a definitive Sikh identity within the overarching account of the amritdhari (initiated) Khalsa (Sikh male identity made distinctive by the five Ks, kesh/long, uncut hair, kara/steel bracelet, kirpan/sword, kangha/comb, and kachha/long underwear) tradition within India and in the diaspora is still riddled with conflicts (Pashaura Singh, Harjot Oberoi, J.S. Grewal, W. H. McLeod, and Khushwant Singh, among many others). Through various reform movements and legal and structural changes (Jakobsh 2015), Sikhs have come to define themselves as distinct from Hindus since the British colonial period to contemporary times. Although the form that came to define and embody what a Sikh is through the amritdhari male (Brian Keith Axel, Jasbir Puar, and Harjot Oberoi, among others), the practice of Sikhi is believed to be varied and plural.

Harjot Oberoi argues in The Construction of Religious Boundaries that there was great diversity in the Sikh panth before the colonial period and certainly until the late nineteenth century (Oberoi 1994). He argues that contemporary Sikhism then became defined and identified by the Khalsa, whereas in earlier times, the definition and practice of Sikhism was more open and inclusive and incorporated many forms and practices. However, his thesis regarding the earlier and myriad Sikh forms that ultimately consolidated into a singular Sikhness drew ire among many traditionalists in the Sikh community. Nikky Singh, who although not actually defending his thesis, calls his narrative a "delightful reading," still finds issues with it, stating, "Oberoi seems to be more at home with the writings of Western sociologists than with that of the Sikhs" (N.G.K. Singh Book Review 1996). Yet, Nikky Singh also writes,

1 For more on Sikh gender identity and resistance, see my forthcoming book, Violence and Resistance in Sikh Gendered Identity (Singh 2019). 
Is Oberoi also mistaking identity for boundaries? With Guru Nanak, Sikh identity is firmly established but boundaries were not demarcated, nor have they been to date. Is it that the author is trying to construct parameters and reify the dynamic and ever-accumulating traditions of Sikhs? Sikh identity is a revisioning and practical living out of the essential and universal truth which lies beyond exclusions and boundaries. (Singh 1996, p. 762)

In other words, even though the dominant Sikh identity is that of the Khalsa within the contemporary Sikh tradition, which Oberoi seems to be arguing for, N.G.K. Singh posits that it is a dynamic and shifting one. Is it? Has it ever shifted to where the Khalsa is seen in the image of the female gender? Or, does it shift and change to accommodate various forms of male Sikh Khalsas?

As Pashaura Singh, in Re-imagining Sikhi ("Sikhness") in the Twenty-First Century: Toward a Paradigm Shift in Sikh Studies states,

It is instructive to note that the Sikh panth [community] has never been a monolithic or homogenous group. Among the twenty-five million Sikhs in the world today approximately twenty percent are the amrit-dharis ('initiated') who represent the orthodox form of the Khalsa. There is, however, a large majority of those Sikhs who 'retain their hair' (kes-dharis) and maintain a visible identity. In particular, the male Sikhs are easily recognized by their beards and turbans. They follow most of the Khalsa rahit ('code') without having gone through the initiation ceremony. (Singh 2013, p. 45)

Pashaura Singh provides various other permutations of the Sikhs, particularly in the diaspora, discussing "mona" or "shorn" Sikhs who are clean shaven but who follow the major precepts of Sikhism. This is similar to my own experiences as I was initiated as an amritdhari in a gurudwara in Burma. For those who follow Sikhism without the outward signs of unshorn hair and turban, he proposes that they be called "ichha-dhari," "one who follows one's own 'desire' or 'free choice'" (Singh 2013, p. 45). For Singh, there are two ways to be "ichha-dhari,": those who "desire" to keep their hair intact but have to cut them due to extenuating circumstances (as we did for our son in the US, although his father chose to keep his hair and beard even in the diaspora) and those who cut their hair out of "choice" but follow the Khalsa way (ibid., p. 45), as I did when I had to work in a minimum wage job as a sales person in a retail store in North Carolina. However, Singh argues that Sikhs can move freely from one category to another as their identities are not "predetermined" or permanently fixed, unlike the caste system in Hinduism (ibid., p. 45). In his analysis, one would assume Sikh identity to be fluid, but in reality, particularly in dominant cultural spaces, it is far from it. One important aspect, in terms of my paper, is that most of the studies regarding Sikhism concern themselves with the outward performance and embodiment of the Sikh through the male body-whether amridhari, mona, or ichha-dhari in India and in the diaspora.

In his article titled, 'Performance' and 'Lived Religion' Approaches as New Ways of 'Re-Imagining' Sikh Studies, Charles M. Townsend writes, "As Sikhs have migrated to places around the world, they have demonstrated remarkable abilities to adapt and thrive within diverse global situations, while sustaining and continuously re/interpreting Sikhism within new contexts" (Townsend 2012, p. 172). He also argues that the new way of "re-imagining" the Sikhs is through the custom of "lived religion" (McGuire 2008) for example in everyday practice (Townsend 2012, p. 172). To understand the idea of "lived religions" in my discussion, we must first ask: What, then, do we mean when we say "lived religions" with everyday practices and the performances of being part of a religious community, particularly as they relate to gender construction within the Sikh diaspora. How is the practice reimagined by women practitioners?

Many Sikh women in India and the diaspora practice Sikhism in traditional ways, as they see Sikhism as a religion of gender equality (Kaur and Moghal, and Dorothy Field, among many others). For example, Kaur and Moghal, after writing about the social reforms of the Sikh gurus where they attempted to abolish unequal ideas such as the impurity imposed on women in childbirth and menstruation ... [their unequal] status in marriage and child marriage, widow remarriage, the practice 
of 'sati', the introduction of mixed congregations and free community kitchen in the gurudwaras, 'dowry', veil wearing and female infanticide, conclude that "The overall picture of Sikhism on women is one of equality and dignity ... [and Sikhism] can be seen as a progressive religion" (Kaur and Moghal 2014, p. 79). However, I argue that there are countless other Sikh women who resist certain traditions for social change and gender equality within the community through practicing forms of Sikh "lived religion" by creating their own ideas of personal religion, yet who attempt to remain within the folds of the Sikh community.

Sikh women have been contesting and transforming gender roles in various national and diasporic — public and domestic — spaces for generations; for example, Amrita Pritam (1919-2005) wrote about religion, love and marriage in her novels, short stories, and poetry and embodied resistance to traditional patriarchal mores during her lifetime (see also Khushwant Singh, Deepti Dharmani, and Anshu Sailpar, among others). As a moni ${ }^{2}$ Sikh in the US since 1984 after I migrated to the US, I used to organize, along with my husband, religious ceremonies in Oregon with other Sikh community members, sometimes with the granthi (ceremonial reader) and the ragis (musicians) from the small Salem gurudwara predominantly run by white American Sikhs, and sometimes just the small community in Corvallis praying and eating langar together. The small Sikh community, a few amritdharis and many clean-shaven—men and women-from India, Kenya, Malaysia, Burma, among others, conducted prayers and served the community. I considered myself a Sikh. Although my role was predominantly within the kitchen, I would occasionally sing kirtans (singing of hymns) with other women; while certain religious expectations, such as being the cook in the kitchen rather than the server where we all sat and partook of the food was irksome to me, I took to lecturing on gender equality to the women and girls and to some of the young men, since I had learned at the Oregon State University's Gender Studies class ${ }^{3}$ to break the silence on gender oppression. While I was being the "good wife and mother" and the langer cook within the Sikh community, I was also practicing a form of resistance by being a role model to my young daughter and other youth about the power of speaking up.

For example, Meredith B. McGuire argues,

There may be enormous diversity - even in relatively stable traditional societies in the gendered aspects of people's lived religions. Especially when we focus on people's everyday beliefs and practices (rather than, for example, formal roles in public rituals), we realize the considerable complexity of all the ways people's religion and spiritually are lined with their gender expectations of self and others, their relationship with human and divine others, and their root sense of identity and community. Religion maybe genuinely ambivalent, serving both as legitimation for institutionally approved traditional gender roles and gender hierarchies and as a source of gender-role contestation, transformation, and innovation. (McGuire 2008, pp. 160-61)

Thus, the ambivalence present in the practice of Sikhi provided me space to participate in religious practices and to resist gender expectations at the same time.

Sikh women practice lived religion within the domestic spaces of the home in various ways; however, the same practices are not accepted within the larger Sikh community. If, for example, as a woman with short hair, I participate in kirtan singing at home, will I still be held as an example of a true Sikh in the gurudwara community? Or, will I, like some community members, hide my short hair under hair extensions, in order to participate in public fund-raising activities in the various gurudwaras

2 Although an amritdhari for most of my young life in Burma, I cut my hair in my teens when I was exiled from Burma to India in the 70s. After I married an amritdhari Sikh, I grew back my hair at his request. When I migrated to the US in 1984, I began cutting my long waist length hair, as I was told by my relatives that I needed to assimilate into mainstream US society if I wanted to succeed in getting a good job. My husband then took the scissors to his thick beard to thin it out to appear groomed for work, although he cried when he did so.

3 I took Gender Studies courses for my MAIS degree (Master in Inter disciplinary Studies). 
around the US? They are only accepted if they "perform" what it means to be a "true" Sikh woman as prescribed by traditionalists-with long uncut hair and certainly married to a patriarchal Sikh man. I know of instances where ideas of compliance and resistance are practiced variously by Sikh women. For example, I know of a woman, born in India but raised in the UK and living for most of her life in the US, took down her Facebook page about her everyday life (with short hair and western-style clothing and occasionally seen in a swimming suit) when she became a hugely successful fundraiser for a Sikh sant (Sikh holy man) in India who was building an educational institution based on the tenets of Sikhism. She then replaced the page with another one with a new photo where her hair appears tied up and covered by a white chunni (scarf) in a submissive stance without any of her children or her clean-shaven mona Sikh husband's photos. Thus, compliance and resistance are closely allied in her Sikh identity, as will also be seen in the authors of my selected essays.

Religion is practiced within a social context, so how, then, do feminists practice forms of lived religion within patriarchal institutions? Nyhagen (along with Khanum Shaikh and Saba Mahmood, among others) show that "agency can be expressed in submission and religious piety as well as in overt oppositional practices that contest men's power and gender inequalities" (Nyhagen 2017, p. 497). Many Sikh feminist scholars and writers work within the religious framework to recover the feminine principle in religion. As Nyhagen claims, "Feminists who work to reform religious traditions from within reject the idea that religions are by necessity patriarchal, and in many religious contexts women have made significant advances towards gender equality" (Nyhagen 2017, p. 496). Feminists such as Shaikh (2013) and Mahmood (2005) show that agency can be acquired through ideas of submission as well as resistance to contest male power within patriarchies. Sikh women practitioners, writers, and scholars function within the Sikh community in India and the diaspora to work with and in opposition to traditional ideas of Sikhism to reimagine and reconstitute gender identity and ideas of equality. For example, Shauna Singh Baldwin, in her novel What the Body Remembers, uses hybridity to tell the story of Sikh women, who are hybrid creatures melded from various cultural influences and looking for a way to work through Sikh cultural and personal traumas. The author had to "pull Sikh women's history out from under Sikh men's history," a history that is not "silent, only undiscovered" (Baldwin 1999). In other words, since females within the Sikh community do not have access, for the most part, to dominant cultural space to tell their stories of gendered oppression and resistance, or they lack the language or words to tell them due to repression, an artist, such as Baldwin, and I, as a critic, can attempt to uncover, retell and reimagine the accounts of feminist resistance. As Svetlana Peshkova, in Women, Islam and Identity: Public and Private Spaces in Uzbekistan, argues, individual Uzbek women's "relational existential power" to Islam, although a practice of individualism, is exercised "in relation" (original emphasis; Peshkova 2014, p. 13) to each other. She adds that "Individuals develop knowledge about a relationship between human and divine worlds by increasing self-knowledge through a practice of thinking, feeling, and acting, which results in a cognitive opening that leads to individual moral change" (Peshkova 2014, p. 14). In other words, while there exists an idea of "national," "traditional," and "politically correct" Islam, Peshkova argues, "individuals are not constituted by but create discourses on religion" (Peshkova 2014, p. 14). Individuals within a nation, society, or community create a notion of personal religion within the larger national or communal religion, as many Sikhs such as myself and Meeta Kaur do within our community in the diaspora for personal and communal empowerment.

Diasporic cultural spaces can often be contentious and conflicted due to the intersections of race, class, sexuality and other social constructs; within these spaces, Sikh identity takes on special meaning and Sikh gender identity becomes specially troubled and troubling. For example, in Gender, Religion and Diversity: Cross-Cultural Perspectives, Anne Sofie Roald argues,

Identity can be divided into smaller components. It has as much to do with how one views oneself, i.e., one's self-definition, as it has to do with how one is perceived by others. In certain situations, self-definition might concur with others' perceptions. In minority/majority conflicts, 
however, others' perceptions tend to be expressed in stereotypical terms. Self-definitions also tend to change according to circumstances. (Roald 2005, p. 186)

In my chosen texts, I attempt to uncover women's negotiation for empowering identities where they resist "others' perceptions" of the amritdhari Sikhs in reductive and masculinist ways, while they reimagine Sikhism through acts of "self-definitions" in their own unique, often ambiguous, ways in the diaspora.

\section{Meeta Kaur and "The Way Home": Negotiating Ambivalent Religious and Cultural Landscapes for Empowerment}

Now that I have laid the edifice of the critical and theoretical framework, along with providing historical and personal contexts, I will discuss in detail some of these self-definitions of what it means to a be a Sikh and what it means to be a Sikh woman in my selected text within the diaspora. In her short essay, The Way Home, Meeta Kaur suggests that she was estranged from her parents' Sikh culture as a diasporic subject, but the return "home" was facilitated by her alliance with an amritdhari Sikh man. The narrative begins with Kaur stating: "It never occurred to me that I'd marry a Sikh, let alone a sardar." ${ }^{4}$ Having grown up with amritdhari Sikh men her whole life, she notes the men in her family always had "turbans that were neatly tied, and their beards were neatly set for both professional and personal events. They often matched their turbans to crisp ironed shirts, neatly tailored slacks," among other things, and even though a "seed of expectation" was sown in her, she "was determined to make [her] own way in the world" (Kaur 2014, p. 209). Reading the ellipses in her text, I can determine that she didn't practice a traditional form of Sikhism, although she saw the males in the family as true Sikhs due to their "neatly tied" turbans and beards, as she suggests she was estranged from her parent's culture. She was surprised, later on, to return "home" to it.

Meeta Kaur had questioned her identity, "Who am I?" and her parents, who she says, "never understood," always gave the same answer, "You are a proud Sikh" or "You are a lion. Our future" (Kaur 2014, p. 210). Her parents expected her to be a Sikh; what that identity was, she didn't know. They never understood, she claims, what she "needs" (ibid., p. 210). After she had "sworn off marriage," however, she finally decides to date online. She flies from California to New Jersey for a conference and from there goes to meet her date in Manhattan. In a telling statement, she says "had my family known, they would have had the police, the FBI, and a SWAT team looking for me" (ibid., p. 211). While she might mean this as a joke, the policing of young women's sexuality and identity in many minority communities, and particularly the Sikh, is apparent in this statement.

When Meeta Kaur meets Banjot, an amritdhari Sikh man, wearing a turban, she also sees another piece of the notables five Ks, "a black strap. [a] ghatra [holding/his kirpan, a scared dagger" (Kaur 2014, p. 211). She declares she was "captivated" by the strap, yet also adds: "I had met people who wore kirpans but never entertained dating a person who wore one" (ibid., p. 211). Clearly, she dated monaor non-Sikhs before she made the decision to seek out an amritdhari male Sikh. She claims that seeing the strap "secured me in the present moment" (ibid., p. 211) and the relationship began to unfold. The relationship with an amritdhari Sikh man signified more than love, for Kaur writes,

Connecting to Banjot reconnected me to my parents. He became the translator for the silence-all they felt was expressed through his simple presence. If they had words for it, I believe they were trying to say, "He is so satisfied within himself as a Sikh. This is what we want for you, so you can live a life of sukh [happiness]." And he translated what my mother could not say: How critical it was for me to discover who I was as a Sikh woman in the world, a Kaur, a daughter of Singhs and Kaurs, a carrier of the Gurus' lineage for future generations. (original emphasis; Kaur 2014, p. 212) 
Let's take a moment to unpack the semiotics of the quote above. Meeta Kaur has not only been alienated from her religion, she has been estranged from her parents as well. She was disconnected from her parents and had faced silence, as she had refused to practice a form of Sikhi that her parents mandated which included not only dating, but also marrying an amritdhari Sikh man. The scenario suggests that dating an amritdhari Sikh man would reestablish Sikhism for Kaur and reconnect her with her parents and her community. She writes, "[Banjot's] unspoken spiritual faith ... [and] his resolve anchored me in my own spiritual journey" (Kaur 2014, p. 212). Her parents' "silence" translated by Banjot's spiritual resolve constructs Kaur as a Sikh woman, for she realizes how important it was for her as a Sikh woman to understand her role as the carrier of future Sikh generations, suggesting Meeta Kaur is merely as a vessel for the future of Sikhism and Sikh heteropatriarchal values, while Banjot becomes the transcendental signifier for true Sikhness. Her earlier form of individual Sikhism without the outward form represented by Banjot's "ghatra" was rejected by her parents, but she had carried on with being a Sikh nonetheless through "a religion-as-lived" (McGuire 2008, p. 15), and through "private conversations [she has always had] with Waheguru" (212). Although she accepts that marrying a turbaned Sikh will return her to true Sikhism, she also attempts to find her own way and path towards religion in her everyday life.

According to McGuire, the "logic" for those who practice "religion-as-lived" are able to experience, rather than simply think or believe in, the reality of her or his religious world (McGuire 2008, p. 13); practicing lived religion "makes sense in one's everyday life, and it needs to be effective, to 'work,' in the sense of accomplishing some desired end (such as healing, improving one's relationship with a loved one, or harvesting enough food to last the winter)" (ibid., p. 15) emphasis added. Kaur practices her Sikhi through the "private" acts of dialogue in order to improve her relationships with her parents and to "hand over every hurt, every doubt, every worry, every concern-to lay them all at His/Her feet and simply step away knowing all will be taken care" (original emphasis; ibid., p. 213). The pain of estrangement from the family will heal, one supposes; here, Meeta Kaur reconstructs the dominant signifier in Sikhism as neither masculine nor feminine but both by using the pronoun "His/Her" for Akal Purakh. She continues to state that it "helped me shed the confines and labels the world places on me as a minority woman or a strong woman of color or a Sikh woman-a this woman, a that woman, a woman - and instead became a beam of light that can merge with the greater world and universe. In turn, I can see the light in everyone I meet" (Kaur 2014, p. 213). She attempts integration and healing through practicing a form of lived religion through seeing the light $-\mathrm{Nur}$-in everyone she meets, while at the same time redefining her self-identity.

Quoting Thich Nhat Hanh, McGuire asserts that practicing "lived religions" can bring "inner awareness and mindful being that produces peace-not merely subjective or personal peace, but indeed the kind of objective effective peace that can end wars and other social violence" (McGuire 2008, p. 13). Kaur remembers past instances of pain at labels, including one that the world had placed on her, that of being a "Sikh woman;" she refuses such labels and gives them up. While the message of light-Awal Allah Nur Upaya-is recited often in Sikhism, the interconnectedness Kaur feels with the universe and other Kaurs come not from practicing an orthodox form of religion, what McGuire calls "institutionally frame[d]" (McGuire 2008, p. 15) religion, but from practicing a form of lived religion. Through the practice of lived religion, Meeta Kaur is able to reach out to other Sikh women whose voices are silenced or unheard through the act of collecting, editing, and publishing Her Name is Kaur: Sikh American Women Write About Love, Courage, and Faith.

\section{Harsohena Kaur and the Daily Prayer: Sikhism as Inscribed on the Body and the Individual Practice of Sikhi}

In another short essay, My Sikhi Simarna, Harsohena Kaur writes about going through a phase of questioning Sikh religious practices, although her love of the Sikh Gurus and their sacrifices were inscribed on her body through her "Naniji's" (maternal grandmother) stories about the torture of Sikh gurus by violent Mughals and their eventual "shaheedi" (martyrdom) (original emphasis; Kaur 2014, 
p.113) when she was very young. Harsohena Kaur, however, learns to question the lack of gender diversity within the gurudwara community: "Where were the women at the moment in Anandpur Sahib where Guru Gobind Singh asked for a Sikh to give up his life? Why didn't He call for the women? Why didn't they answer the call? Were they even allowed to answer the call?" (Kaur 2014, p. 118). She is appalled by the truth that even now, "neither [her] sister Sikhnis nor [she] are allowed to do seva (community service through being elected as gurudwara management committee members) in the inner sanctum" of the gurudwara (Kaur 2014, p. 118). By "inner sanctum," Kaur may also mean being elected to the position of Jathedar of the Akal Takht, the highest temporal seat of the Sikhs, or she must also mean being the head granthi or president of a Sikh gurudwara; or she may simply mean being able to distribute the food in the langar hall as opposed to being cooks in the community kitchen (see my discussion of Sharanpal Ruprai or my own example for the feminization of certain seva as opposed to being resisted to cooking in the kitchen). Such discriminatory practices lead to "hurt, anger and frustrations at the broken promises and the unfairness against women" which become a "pulsating bead" in her "simarna" (prayer) (Kaur 2014, p. 118). She rejects dominant religious narratives about what it means to be a Sikh, and particularly a Sikhni, and attempts re-inscription and an individual form of lived religion through resistance.

Harsohena Kaur's retrospective looks at the 1984 Sikh Massacre in India and the "choices" women made to "sacrifice" their sons and husbands for the cause of Sikhism when they refused the demands of the crazed Hindu mobs to cut off their sons and husbands' hair and who were eventually murdered, lead her to question her faith (Kaur 2014, p. 119). Did the woman who took her sons in, tied their dastaars (turban) and said (as the mobs demanded her to bring out her sons), "They are not my sons. They are guruji's sons" (ibid., p. 119) perform true Sikhism? The woman narrating the story to Harsohena Kaur quietly said, "The mobs just smashed kerosene bags on their heads and set them on fire" (Kaur 2014, p. 119). The collective trauma of the violence of 1984 leads Kaur to ask,

Would I do the same? Is that courage or insanity? Was there even a choice, given the intent of the mob? Was she at peace that they had died in saroop (outward appearance of the Sikh) rather than have their hair shorn? Or did she wonder if they would have been spared had she cut their hair? Was this vile hate really the will of the Waheguru? (Kaur 2014, p. 119)

While the event of 1984 solidified her Sikhi, she still faced many "challenges and choices" which "determines the course," writes Harsohena Kaur, of the Sikhs' future (ibid., p. 119). What were those challenges and choices? "As an almost adult," she notes, "she fell in love with a non-Sikh" (ibid., p. 119), and even though it was predominantly a "long distance" relationship "via letters," it led to an internal struggle "between the reality and three-dimensionality of [her] flesh and blood love and the abstract reality and a love for [her] religion" (ibid., p. 120). She asks, "Did I have the right to give it all up for my personal desire? Or did I need to sacrifice those desires to fully realize my faith?" (Kaur 2014, p. 120). She finally came to the realization that it was not her "Sikhi that was making [her] hesitate" but the "pragmatic" realization that she needed "commonality" of the Sikh practice with her life partner (ibid., p.120). Her sister had married a non-Sikh and was estranged from her natal family (ibid., p. 121). Following traditional norms, when a woman marries outside of the community, she is either thrown out of the family or excommunicated from the Sikh community at large. ${ }^{5}$ Regarding her sister, Harsohena Kaur claims, "These were actions beyond the realm of even imagined possibility and tore our family apart. For years, the sheer disbelief paralyzed us, and the hurt and pain bled like a non-healing wound" (ibid., p. 121). This crisis in the family led her to question individual choices versus communal well-being. Her fear and her pragmatism led her to "choose" an amritdhari Sikh man. She soon met "an unbelievably smart and handsome sardar with a super-wattage smile and

5 I know of a case where a Sikh woman married a man of another race and the family not only threw her out of the house, there was even a discussion of honor killing; one male member of the family said, "If a finger becomes rotten, then it is best to cut it off to save the hand." 
amazing energy" to whom she said "yes," and whose presence provides her with a non-feminine perspective of what being a Sikh means (ibid., p. 121). Having grown up with only sisters, she only had the "feminine" perspective of Sikhi (ibid., p.121). She writes, "Now I walk beside my turban-wearing husband, I realize how much that charges him with being different. He stands out, stands apart, and stands alone. And my son follows the same path" (ibid., p.121). Her husband is proud of his Sikhi and looks on his turban as a "way to leave his mark" (ibid., p. 122). She writes, "I hope my son lives with that sense of pride as well" (ibid., p. 122). When faced with loneliness or troubles, she says her faith and the reading of the Guru Granth Sahib sustains her.

While being aware of Sikhi in terms of the masculine form and hoping her son will follow the path, she mentions her daughter only once in the essay when she talks about gender discrimination and domestic violence within the Sikh community; she mentions the silence about gender oppression. "How," asks Harsohena Kaur, "do we give life to women's dreams" (Kaur 2014, p. 122)? Her hope for her daughter's dreams is a "bead" in her "simarna," her prayer. While she makes life changes in order to continue to be part of the Sikh community and upholds the traditions and customs as far as her husband and son are concerned in concrete actions of their turbans and long uncut hair, her actions for her daughter's identity and future are translated to prayers and telling of the beads, of "simarna." Will the telling of the beads allow her daughter to provide seva in the inner sanctum of the Sikh religious gurudwara spaces? Will it end gender discrimination in the Sikh community and religious sites? Her role in the Sikh community is that of mother, the one who transmit knowledge of "Gurmukh" life, hoping the same will be replicated in her children's life. Her choices are limited, so she finds a way to be with Waheguru—through "simarna" and prayers.

Thus, in Harsohena Kaur's practice of Sikhi, it is through marrying a gursikh, an amritdhari, that she is enabled to stay within the community. While the same may not provide gender equality, as she still thinks about the various heteropatriarchal and heterosexist practices within the Sikh religious spaces, she negotiates these by making sure that her son and husband will remain amritdhari so that Sikhism may continue to flourish; women, in this scenario, although merely the vessel, the ghara, that holds the knowledge empowering male Sikhs, while women remain in subordinated positions within the "inner sanctum" (Kaur 2014, p. 118)—read as the kitchen area of the gurudwara-they attempt to form an individual relationship with the divine through submission and hoping for gender equality for the next generation of women by asking, "How do we give life to women's dreams?" Is there hope for gender equality for Sikh girls and women in the context of Sikh male violence-ones perpetrated on male Sikh bodies and ones perpetrated by them? Is she hoping that as readers of her texts, feminist critics such as myself, might address the issues of gender oppression within the Sikh traditions and create a circle of care for each other? One continues to hope.

\section{Harleen Kaur and the Sikh Turban: Resistance, Appropriation and Self-Empowerment}

For some young women, being Sikh and practicing Sikhi, being marginalized in the "inner sanctum" (Kaur 2014, p.118), not being allowed to provide seva in the main langar hall, but only in the kitchen (see Kaur 2014 and Ruprai 2014, among others), cause them to change and alter the meaning of, or rather the performance of, gender. If gender is a performance (Butler) and a masquerade (Riviere 2013), can Sikhness too, as a social construct, be performed in alternative or transformative ways, in subversive or resistant ways? While the following narrative by Harleen Kaur titled Moving Forward (sic) may not provide examples of young women appropriating the male turban for empowerment in any institutional way, there are many instances of individual women taking up the turban, particularly in the diaspora, although, of course, there are many instances of these moments occurring in India as well (see Mahmood and Brady's The Guru's Gift (Mahmood and Brady 1999) for more on the phenomenon of women donning the Sikh turban in the diaspora). However, while individual women have donned the turban for empowerment and to practice Sikhi in their own individual ways, it is still the amritdhari Sikh male that becomes the epitome of Sikhness and women continue to be sidelined and marginalized, as seen in Harleen Kaur's Moving Forward when she heard about the 2012 shooting 
and killing of Sikhs at the Oak Creek gurudwara in Wisconsin. Harleen realizes that one of the persons who has been murdered was her music and kirtan teacher, Satwant Singh Kaleka, "an uncle," from the gurudwara community she used to mingle and pray with before she moved on to live in Plymouth, Michigan. In Plymouth, "strangers [approached]" the male members of the Sikh community and provided "condolences" to them, but such gestures of sympathies were never personally provided for her. She thought, "Well, I'm a Sikh. Why doesn't anyone talk to me?" She continues, "That's when it hit me: I don't look like a Sikh" (p. 233). She realized that she has been saying to people all along that the "most visible identifier of the Sikh" is the turban (ibid., p. 234), yet here she was, she rationalizes, being marginalized because she herself has not "accepted the Sikh identity" (ibid., p. 235). Here the Sikh identity is clearly equaled with the male turban. In the formation of the Khalsa, according to Jakobsh, "Traditional male roles became increasingly valued and female roles devalued with the institutionalization and politicization of the Sikh panth. While there were exceptions to the rule, the ethos dominating the developing Sikh community was clearly patriarchal, hierarchical, and masculine" (Jakobsh 2015, p. 43). As a diasporic Sikh woman, I, too, have been at the receiving end of this hierarchical patriarchal treatment, particularly as it pertains to the Sikh practice; within our home, when I was married to a keshdhari (a Sikh that wears the $5 \mathrm{ks}$, but is not formally initialed) Sikh, whenever we had path (prayer) or kirtan at our home, my then husband took up the role of granthi and performed ardas (formal prayer of supplication). I, on the other hand, was relegated to the kitchen seva (service) and could, at the most, contribute a kirtan after begging or cajoling to do so, and it could only typically be poota mata ki asees (a mother's blessing; the word "poota" is traditionally understood as "son"). Although, as I had noted above, I found ways to resist patriarchal ghettoization through either discussion of gender equality with younger community members or by playing the dholak and singing provocative Punjabi folk songs, my Sikhi is considered secondary by patriarchal norms and by the Sikh community members in relation to my turbaned husband, as I'm considered patit, or lapsed Sikh.

Through trying to come to terms with the Sikh gurudwara shooting tragedy and through learning about the impermanence of life, through trying to recognize the ability of non-Sikhs to understand the Sikh community, through trying to find an empowering space within the predominantly patriarchal Sikh tradition, Harleen Kaur took a radical step. She claims, "I have been wearing the dastaar (turban) for over a year now, but every day is a struggle" (original emphasis; Kaur 2014, p. 235). She knows by donning the turban, she will practice her Sikhi in an individual, although ambiguous, manner-in the manner of the male Khalsa Sikh—but she also understands that the struggle will continue on: "I will continue to question and work on myself in the coming days, weeks, and years, but I will never question my progress. Because no matter how difficult or frustrating it seems, it is all truly that. Progress" (Kaur 2014, p. 235). Thus, for Harleen Kaur, her Sikhi leads her to taking up a masculinist attire, and although it will lead to constant struggle due to her ambivalent position in the in-between spaces of the gurudwara, she will continue on to live and fight like a man, for in the epigraph, she uses the following quote from Jorge Luis Borges, "Any life is made up of a single moment, the moment in which a man finds out, once and for all, who he truly is" (Kaur 2014, p. 230). Social construction of gender and religion has predominantly provided space for the patriarchal male as dominant; it is also true in the Sikh tradition and community. As McGuire notes, while religions

Provide myths and symbols of origin and creation ... offer narrative of redemption, healing and salvation ... [are] captivated by the lure of the divine and the all-consuming, all-transforming fire of the spirit. [It has] also created and legitimized gender, enforced, oppressed and warped it, but also subverted, transgressed, transformed and liberated it. (McGuire 2008, p. 8)

The three Sikh cisgendered women's narrative that I analyze here provide an examination of Sikh tradition and the space available for cis women to participate in Sikh traditions while also practicing forms of lived religion through resistant practices. While Meeta and Harsohena Kaur practice Sikhi through an alliance with amritdhari males to reclaim the Sikh panth (community) and communal spaces for the family, Harleen Kaur crosses the gendered space and appropriate male-centric tools to be able 
to negotiate from an in-between and ambivalent, although often individual and isolated, space her identity as a true Sikh.

\section{Mandeep Kaur and Neesha Kaur: Gender, Difference and the Personal Experience of the Gurbani}

In Mandeep and Neesha Kaur's "A Different Kind of Love," we understand what it means for them to be practicing Sikhi as members of the queer community. Mandeep and Neesha met as two freshman college students. Told from the perspective of both Mandeep and Neesha alternatively, the narrative encompasses both their journey into love-a "different kind of love story" (Kaur and Kaur 2014, p. 112)—for two Sikh women who navigate cultural, sexual, and religious boundaries to understand and accept each other. Almost two years after they met and became friends, Neesha continues to try to understand her growing attraction to Mandeep, but unable to articulate her desire for her, she sees her walk away "in the arms of someone else" (Kaur and Kaur 2014, p. 108). At this point, she realizes that she couldn't be with someone like Mandeep; she writes, "My family and culture would never accept it. The harder I tried to compose myself, the more my heart would hurt" (Kaur and Kaur 2014, p. 108). Here, we understand that due to her Sikh family and her Indian American culture, where heterosexism is dominant, homosexual love was not going to be easily accepted. Additionally, as Takhar, et al. note, "Sikh women are subject to a high degree of surveillance in their daily lives both physically through the censure by parents and peers of dress, appearance and demeanor but also more profoundly through cultural expectations which impinge on their sense of self" (Takhar et al. 2008, p. 100). This idea of surveillance is particularly harsh in the diaspora and more so after 9/11 and the various attacks against the amritdhari Sikh bodies (see Puar 2017 and Axel 2001, among others). Eventually, however, Neesha tells Mandeep, "I really like you, and I've taken a long time to think about it, but I really want to be with you" (Kaur and Kaur 2014, p. 111). Afterwards, they both go to the park and hold hands; Mandeep writes, "I knew she was the one. She has always been the one" (Kaur and Kaur 2014, p. 111).

The end of the narrative merges both their voices.

I am a Sikh woman, and I fell in love with another Sikh woman. It doesn't matter that she was a man or a woman because I fell in love with her soul. Love is meant to be the harmony of two souls, not two pieces of the puzzle of what our culture expects. Within the realm of society, our love story puts us at risk of discrimination and harm from our families and community ... For me, Sikhi was always a personal experience of the gurbani that should not be judged. I never rejected Sikhi, but rather the culture associated with the religion. Sikhi does not teach hate or discrimination, but people do. (Kaur and Kaur 2014, p. 112)

As can be seen from above, Mandeep and Neesha, lesbian lovers, reconstruct what it 'means to be a Sikh,' thought as individuals as they will most likely lose their community. They re-signify meaning in ways that Sikhi becomes a personal and not collective experience of the gurbani; and even though Sikhism is religious as well as cultural, they reject the cultural component of it. Thus, for them, being Sikh does not translate to the tradition of the heteropatriarchal male Sikh as the transcendental signifier of Sikhism and of Sikhi. It means to be able to see the personal journey of being Sikh and practicing Sikhi through the practice of gurbani and of love.

In spite of individual women resisting or appropriating certain cultural norms and practice a form of lived religion through individual acts, as I've discussed above, I argue that the majority of the narratives in Her Name is Kaur privileges the heteropatriarchal amritdhari Sikh male as the transcendental signifier of Sikhism and continue to define Sikhi and Sikhism through the masculinist idea of the turbaned male amritdhari Sikh-yet, I also argue, these women are able to create an individual connection with Waheguru through the practicing forms of lived religions.

The discussion supports my argument that when we think about Sikhs within dominant cultural spaces, the turbaned amritdhari male Sikh body is privileged as the embodiment of the Khalsa. Women 
attempt to wrest power within communal spaces as practicing Sikhs either through resistance or through appropriation of the idea of the "true" Sikh. There are those who attempt resistance and move in and out of social and cultural spaces to reclaim an individual Sikh religious identity, as Mandeep and Nisha certainly do and as Meeta Kaur, Harsohena Kaur, and Harleen Kaur continue to struggle to do. However, within the majority of the selected narratives from Her Name is Kaur, the narrators are aware of what it means to be Sikh in terms of the male body-the turbaned amritdhari Sikh with the five Ks intact.

Within my own extended family in Burma, India, and the USA, the majority of the religious ceremonies within the gurudwaras or within our home are undertaken by male keshdhari turbaned Sikhs (whether amritdhari or not), as they embody what is understood as true Sikhism in the dominant cultural spaces of the Sikh community. When women participate in the ceremonies, they partake in kirtan singing and the preparation of the langar. My paternal grandmother, who was born and raised in Rawalpindi, Punjab (pre-Partition), but who lived her entire adult life in Burma, used to recite the ardas in our home in Burma, but within my extended family in India and within the US, it is always a male amritdhari Sikh who recites it. Yet, the majority of the women recite the daily prayers as Sikhs and even though some of us have short hair, we never felt we were unable to have a personal relationship with the Akal Purakh, the eternal and timeless being. We do, however, feel that within the gurudwara and dominant cultural spaces that we are always relegated to a secondary position, as wives, daughters or mothers of the male Sikh and as "impure" Sikhs due to our short hair. Within this troubled gendered space, women continue to negotiate, navigate, and practice forms of lived religion as Sikhs, even though the idea of who a true Sikh is and what form it takes continues to haunt the debates within the Sikh community and the daily lives of Sikh women in the diaspora.

Funding: This research was funded by Northern Michigan University Reassigned Time Award which provided me one course credit for professional development

Conflicts of Interest: The author declares no conflict of interest.

\section{References}

Axel, Brian Keith. 2001. The Nation's Tortured Body: Violence, Representation and the Sikh "Tortured" Body. North Carolina: Duke University Press.

Baldwin, Shauna Singh. 1999. What the Body Remembers. New York: Doubleday.

Didur, Jill. 2006. Unsettling Partition: Literature, Gender and Memory. Toronto: University of Toronto Press.

Jakobsh, Doris R. 2003. Relocating Gender in Sikh History. London: Oxford University Press.

Jakobsh, Doris R. 2015. Seeking the Image of 'Unmarked' Sikh Women Text, Sacred Stiches, Turban. Religion and Gender 5: 35-51. [CrossRef]

Kaur, Meeta, ed. 2014. "Introduction" and "The Way Home". In Her Name Is Kaur: Sikh American Women Write about Love, Courage, and Faith. Berkeley: She Writes Press.

Kaur, Harleen. 2014. Moving Forward. In Her Name Is Kaur: Sikh American Women Write about Love, Courage, and Faith. Edited by Meeta Kaur. Berkeley: She Writes Press.

Kaur, Harsohena. 2014. My Sikhi Simarna. In Her Name Is Kaur: Sikh American Women Write about Love, Courage, and Faith. Edited by Meeta Kaur. Berkeley: She Writes Press.

Kaur, Mandeep, and Neesha Kaur. 2014. A Different Kind of Love Story. In Her Name Is Kaur: Sikh American Women Write about Love, Courage, and Faith. Edited by Meeta Kaur. Berkeley: She Writes Press.

Kaur, Parveen, and Arif Jawaid Moghal. 2014. Lotus in the Pond: The Symbolization of Women in Sikhism. International Review of Modern Sociology 40: 65-81.

King, Ursula. 2005. General Introduction. In Gender, Religion and Diversity: Cross-Cultural Perspectives. Edited by King Ursula and Tina Beattie. London: Bloomsbury Publishing.

Kopf, Martina. 2009. Trauma, Narrative and the Art of Witnessing. In Slavery in Art and Literature: Approaches to Trauma, Memory and Visuality. Edited by Birgit Haehnel, Melanie Ulz Frank and Timme. Berlin: Frank \& Timme GmbH, pp. 41-58. 
Lugones, Maria A. 2003. Peregrinajes/Pilgrimages: Theorizing Coalitions against Multiple Oppressions. Lanham: Rowman and Littlefield.

Mahmood, Saba. 2005. Politics of Piety: The Islamic Revival and the Feminist Subject. Chicago: University of Chicago Press.

Mahmood, Cynthia, and Stacy Brady. 1999. The Guru's Gift: An Ethnography Exploring Gender Equality with North American Sikh Women. New York: McGraw-Hill.

McGuire, Meredith B. 2008. Lived Religion: Faith and Practice in Everyday Life. Cary: Oxford University Press, Incorporated.

Nyhagen, Line. 2017. The lived religion approach in the sociology of religion and its implications for secular feminist analyses of religion. Social Compass 64: 495-511. [CrossRef]

Oberoi, Harjot. 1994. The Construction of Religious Boundaries: Culture, Identity, and Diversity in the Sikh Tradition. Chicago: University of Chicago Press.

Peshkova, Svetlana. 2014. Women, Islam, and Identity: Public Life in Private Spaces in Uzbekistan. Syracuse: Syracuse University Press. First published 2011. Available online: www.tribuneindia.com/2001/20010701/spectrum/ main1.htm (accessed on 17 October 2019).

Puar, Jasbir. 2017. Terrorist Assemblages: Homonationalism in Queer Times. Duke: University Press.

Riviere, Joan. 2013. Womanliness as a Masquerade. In The Routledge Critical and Cultural Reader. London: Routledge.

Roald, Anne Sofie. 2005. Gender, Religion and Diversity: Cross-Cultural Perspectives. In Gender, Religion and Diversity: Cross-Cultural Perspectives. Edited by King Ursula and Tina Beattie. London: Bloomsbury Publishing.

Ruprai, Sharanpal. 2014. Seva. Toronto: Frontenac House.

Shaikh, Khanum. 2013. Gender, Religious Agency, and the Subject of Al-Huda International. Meridians: Feminism, Race, Transnationalism 11: 62-86. [CrossRef]

Shaw, Susan M., and Janet Lee, eds. 2015. Women's Voices, Feminist Visions: Classic and Contemporary Readings. New York: McGraw Hill.

Singh, Nikky-Guninder Kaur. 1996. Reviewed Work: The Construction of Religious Boundaries: Culture, Identity, and Diversity in the Sikh Tradition by Harjot Oberoi. The Journal of Asian Studies 55: 760-62.

Singh, Khushwant. 2001. "The Sikhs". The Tribune. Sunday. July 1. Available online: www.tribuneindia.com/2001/ 20010701/spectrum/main1.htm (accessed on 11 February 2019).

Singh, Pashaura. 2013. Re-Imagining Sikhi ('Sikhness') in the Twenty-First Century: Toward a Paradigm Shift in Sikh Studies. Leiden: Brill, vol. 141, pp. 25-48.

Singh, Nikky-Guninder Kaur. 2014. Preface. In Her Name Is Kaur: Sikh American Women Write about Love, Courage, and Faith. Edited by Meeta Kaur. Berkeley: She Writes Press.

Singh, Jaspal Kaur. 2019. Violence and Resistance in Sikh Gendered Identity. London: Routledge.

Takhar, Amandeep, Parsons Elizabeth, and Maclaran Pauline. 2008. Gender, Self-Discovery and Identity Conflict on a Sikh Dating Website, Advances in consumer research. Association for Consumer Research (U.S.). vol. 9. Available online: www.academia.edu/1535175/Gender_Self_Discovery_and_Identity_Conflict_on_a_Sikh_ Dating_Website (accessed on 14 February 2019).

Townsend, Charles M. 2012. 'Performance' and 'Lived Religion' Approaches as New Ways of 'Re-Imagining' Sikh Studies. In Re-Imagining South Asian Religions: Essays in Honour of Professors Harold G. Coward and Ronald W. Neufeldt. Edited by Pashaura Singh and Michael Hawley Jr. vol. 141, pp. 171-91, ProQuest Ebook Central. Available online: https:/ebookcentralproquestcom.nmu.idm.oclc.org/lib/nmich/detail.action?docID=1158503 (accessed on 17 October 2019).

Whitlock, Gillian. 2015. Postcolonial Life Narratives: Testimonial Transactions. London: Oxford University Press.

(C) 2019 by the author. Licensee MDPI, Basel, Switzerland. This article is an open access article distributed under the terms and conditions of the Creative Commons Attribution (CC BY) license (http://creativecommons.org/licenses/by/4.0/). 